\title{
Fatigue Analysis of Catenary Mooring System due to Harsh Environment in Head Seas
}

\author{
Fuad Mahfud Assidiq ${ }^{\mathrm{a}, *}$, Daeng Paroka ${ }^{\mathrm{b}}$, Muhammad Zubair Muis Alie ${ }^{\mathrm{c}}$, Syerly Klara ${ }^{\mathrm{d}}$ \\ ${ }^{a}$ Ocean Engineering, Faculty of Engineering, Hasanuddin University. Email:fuadassidiq9@ gmail.com

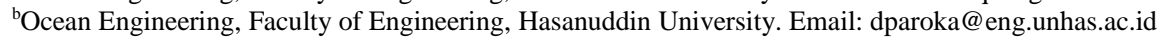 \\ ${ }^{\mathrm{c} O c e a n}$ Engineering, Faculty of Engineering, Hasanuddin University. Email: zubair.m@eng.unhas.ac.id \\ ${ }^{\mathrm{d}}$ Marine Engineering, Faculty of Engineering, Hasanuddin University. Email: elikapal83@ gmail.com
}

\begin{abstract}
The Floating Production Unit (FPU) is a floating gas production barge that is moored by catenary mooring system to the seabed. In the operation, FPU will be impacted by dynamic loads such as ocean waves, ocean currents, and winds on the mooring line structure periodically. This may cause damage to the mooring line structures which effect the operational structure performance. The aim of the present study is to investigate fatigue life on catenary mooring system. The model studied refers to the comparison of with and without using the Single Line Freestanding Riser (SLFR), the operational design and installation conditions are located in the Makassar Strait. The dimensions of mooring line type six-strand wire rope are 0.115 meters of outer diameter and 1,200 meters of length then it will be analyzed of fatigue life. The FPU motion observation in head seas shows the highest Response Amplitude Operator (RAO) of surge, sway, heave, roll, pitch, and yaw motion due to harsh environments with $H_{s}=4.0$ meters and $T=7.7 \mathrm{sec}$ are obtained $0.615 \mathrm{~m} / \mathrm{m}, 9.354 \times 10^{-7} \mathrm{~m} / \mathrm{m}, 1.048 \mathrm{~m} / \mathrm{m}, 18.423 \times 10^{-6} / \mathrm{m}, 2.225$ $0 / \mathrm{m}$, and $12.671 \times 10^{-8} / \mathrm{m}$. It means that the response amplitude will always be smaller than the wave incident amplitude. The using SLFR has longer frequency about $0.207 \mathrm{rad} / \mathrm{sec}$ than without using SLFR. Taking into RAO motion calculation, the fatigue life on catenary mooring systems for head seas using SLFR is 412 years in mooring line 4 and 5 . the fatigue life on catenary mooring systems for head seas without using SLFR is 6,636 years in mooring line 5. The structure is still in safe condition because of the design safety factor is about 300 years.
\end{abstract}

Keywords: Catenary; fatigue life; head seas; response amplitude operator; single line freestanding riser

\section{Introduction}

The Floating Production Unit (FPU) Gendalo-Gehem Chevron Indonesia Company, which is Indonesian Deepwater Development (IDD) mega project, is located in the Makassar Strait about 6.000 feet depths as shown in Fig. 1. The project will include two development hubs, FPU with subsea drilling center, and condensate pipelines and onshore facilities. The natural gas will be used domestically and converted to LNG in Bontang, East Kalimantan. The maximum daily production is expected to 1.1 billion cubic feet of natural gas and 31,000 barrels of condensate.

In this gas production phase, FPU will be impact by ocean waves, ocean currents and winds due to highest FPU motions and the highest stress responses of the catenary mooring system while gas production process can damage these structures and other operational load factors. Consequently, it gets more critical conditions.

Moreover, the fatigue analysis is the most important effect in the FPU construction and production development. This research will discuss the fatigue analysis of the catenary mooring system to determine the fatigue life with SLFR and without SLFR in head seas for six degrees of freedom (surge, sway, heave, roll, pitch, and yaw motion).

${ }^{*}$ Corresponding author. Tel.: +62-856-9652-0325

Jalan Poros Malino km. 6, Bontomarannu

Gowa, Sulawesi Selatan, Indonesia, 92171 


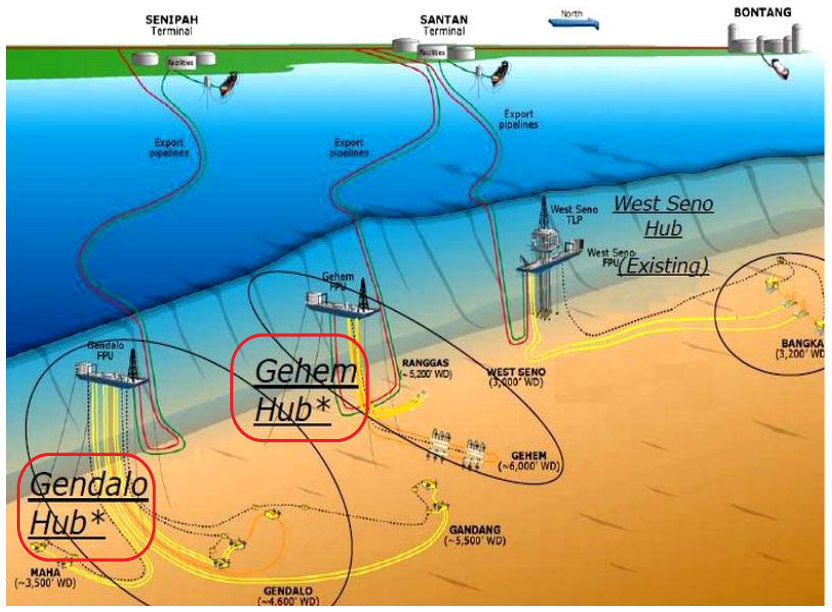

Figure 1. Gendalo-Gehem field

\section{Literature Review}

\subsection{Ship Theory}

Basically, floating objects have six degrees of freedom which are divided into two groups which are first, three translational modes (surge: $\mathrm{X}$-axis transversal direction, sway: $\mathrm{Y}$-axis transversal direction, and heave: Z-axis transversal direction) and three rotational modes (roll: $\mathrm{X}$ axis rotational direction, pitch: Y-axis rotational direction, and yaw: Z-axis rotational direction). By using right hand axis system, the definition of six degrees of freedom mode can be explained in Fig. 2 [1]. The current study discusses surge motion. The surge motion system does not have stiffness element. As an illustration when the ship is moving then the added mass due to fluid particles movement around it.

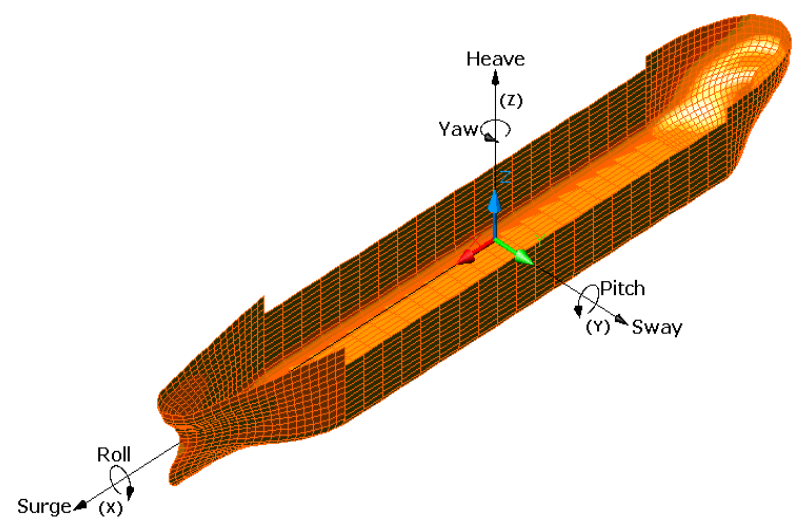

Figure 2. Six degrees of freedom on floating unit

The motion direction is affected the wave heading angle $(\mu)$, which is the angle between the direction of wave propagation and the ship direction rate. The angle setting of wave heading can be seen in Fig. 3, and Table 1 [2].

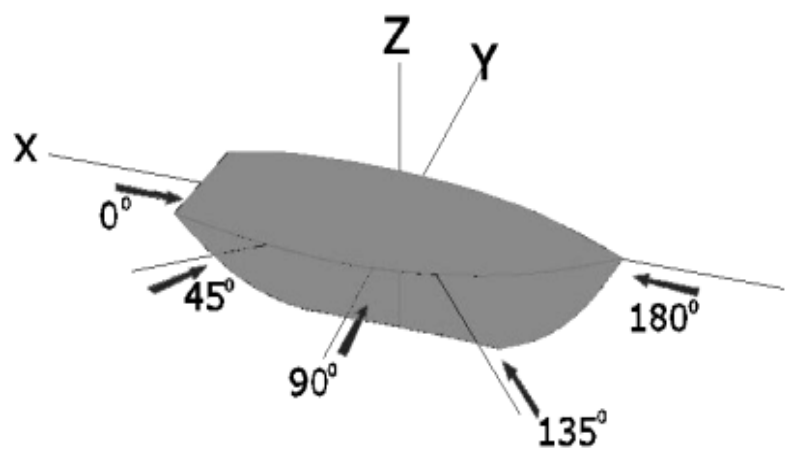

Figure 3. Heading direction in Ansys software

Table 1. Main heading on floating unit

\begin{tabular}{ll}
\hline Heading & Description \\
\hline $0^{\circ}$ & Following Seas \\
$45^{\circ}$ & Stern Quartering Seas \\
$90^{\circ}$ & Beam Seas \\
$135^{\circ}$ & Bow Quartering Seas \\
$180^{\circ}$ & Head Seas \\
\hline
\end{tabular}

Response Amplitude Operator (RAO) is a tool to the wave forces transfer into the dynamic response of structures. $\mathrm{RAO}$ equation can be expressed as [3]:

where:

$$
R A O(\omega)=\frac{X p(\omega)}{\eta(\omega)}
$$

$X p(\omega)=$ Structure amplitude (meter)

$\eta(\omega) \quad=$ Wave amplitude (meter)

\subsection{Mooring System}

Mooring systems typically have 8 to 16 mooring lines consist of the heavy chain, steel wire rope and polyester materials that connect anchor toward the seabed [4]. The catenary system paths arrive at the seabed horizontally, although taut mooring tethered to an angle formed [5]. Another important difference is that the strength of the recovery on the catenary mooring generated by the weight of the components while the taut mooring strength comes from the elasticity of the mooring lines.

When oil and gas extraction takes place from shallow water into deep water, the catenary mooring system is more popular but when identification of deep water production into ultra-deep water, mooring system becomes the limit factor. To solve this problem, a new solution was developed as taut leg mooring system. In Fig. 4 shows the mooring system configurations [6]. 


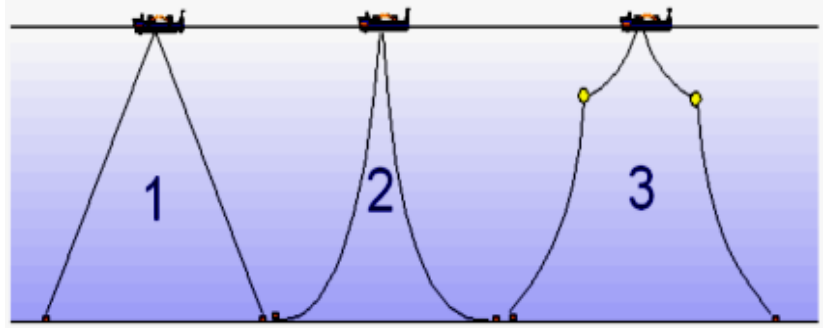

Figure 4. Mooring system configurations;

(1) taut mooring; (2) catenary mooring and (3) catenary mooring with buoyancy

Tension which happens to the mooring line can be divided into two: the mean and maximum tensions. Mean tension is tension on the mooring line related to the mean offset of the vessel while the tension is the mean maximum tension under the combination effect of wave frequency and low-tension frequency [7].

The tension limit on the mooring line and safety factor recommended by American Petroleum Institute are as follows [8]:

Table 2. Criteria and tension limit safety factor mooring

\begin{tabular}{llll}
\hline Case & $\begin{array}{l}\text { Analysis } \\
\text { Method }\end{array}$ & $\begin{array}{l}\text { Tension Limit } \\
\text { (Percent of MBS) }\end{array}$ & $\begin{array}{l}\text { Equivalent } \\
\text { Factor of Safety }\end{array}$ \\
\hline Intact (ULS) & Dynamic & 60 & 1,67 \\
\hline
\end{tabular}

\subsection{Fatigue Analysis}

The fatigue analysis is defined as research that includes global dynamic motion and local stress of catenary mooring tension. The existing methodology does not have the consistency and transparency level necessary to independently demonstrate the safety level and conservatism in the design of the catenary [9].

The basis of the S-N curve is mentioned between the plot of stress $(S)$ and the number of cycles $(N)$. This curve is used to express the characteristics of fatigue in materials due to cycle loads at a constant magnitude [10]. The accuracy level is affected by the determination of $\mathrm{S}-\mathrm{N}$ curve slope parameter and interception, the analytical expression of the S-N curve is [11]:

where:

$$
N i(s)=a D \cdot s^{-m}
$$

$\mathrm{Ni}(\mathrm{s})=$ Cycle of failure

$s \quad=$ Stress range $\left(\mathrm{N} / \mathrm{mm}^{2}\right)$

$a D=$ Intercept parameter in $\mathrm{S}-\mathrm{N}$ curve

$m \quad=\mathrm{S}-\mathrm{N}$ curve slope

Meanwhile, $a D$ and $m$ parameters explanation are given in Table 3 and S-N curve is shown in Fig. 5.

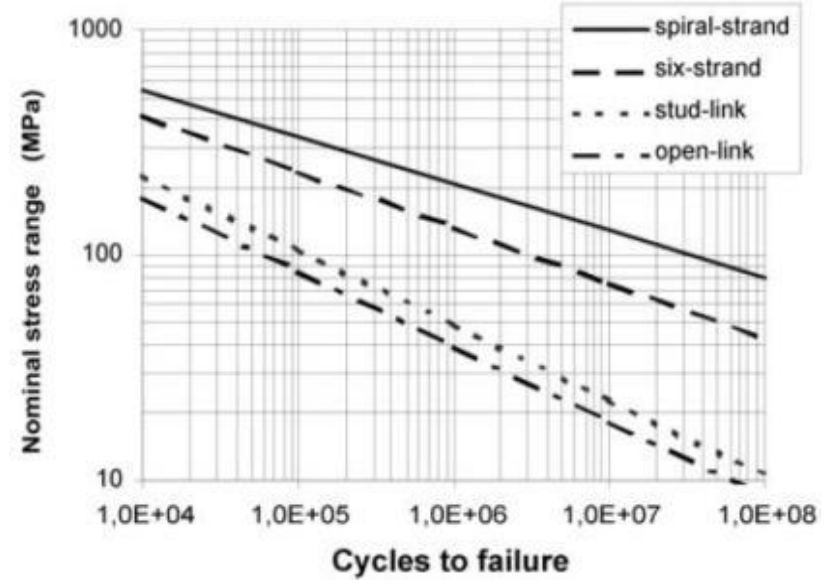

Figure 5. S-N curve

Table 3. S-N curve parameter

\begin{tabular}{lll}
\hline Mooring Types & $a D$ & $m$ \\
\hline Stud Chain & $1.2 \times 10^{11}$ & 3.0 \\
Studless Chain (Open Link) & $6.0 \times 10^{10}$ & 3.0 \\
Six-Strand Wire Rope & $3.4 \times 10^{14}$ & 4.0 \\
Spiral Strand Wire Rope & $1.7 \times 10^{17}$ & 4.8 \\
\hline
\end{tabular}

Each mooring lines take the fatigue life further process between the number of cycles-stress range and mooring line characteristics [12]. This fatigue life review when the condition of the surge, sway, heave, roll, pitch and yaw motion by heading $180^{\circ}$ (head seas) were calculated as follows [9]:

$$
\begin{aligned}
& n=\frac{T}{T a} \\
& D=\sum_{i=1}^{n} \frac{n}{N i}
\end{aligned}
$$

where:

$$
\begin{array}{ll}
\mathrm{n} & =\text { Number of cycle } \\
\mathrm{D} & =\text { Fatigue damage ratio } \\
\mathrm{T} & =\text { Design life period }(\mathrm{sec}) \\
\mathrm{Ta} & =\text { Stress range period }(\mathrm{sec}) \\
\mathrm{Ni} & =\text { Cycles of failure }
\end{array}
$$

While the fatigue life calculations (in years) are from the total fatigue damage, and the safety factor at least about 10 [13], and additional safety between 0 and 1 .

$$
\text { Fatigue Life }=\frac{1}{N i \times(10+\text { additional safety })}
$$

As well as the fatigue life in safety design criteria for mooring lines as follows [14]:

$$
\text { Fatigue Life }>\text { Design Life }
$$




\section{Research Methods}

The research was conducted by literature review and FPU supporting data as in Table 4, Table 5, and Table 6. The FPU simulation with and without using SLFR in head seas investigate the fatigue life on catenary mooring system. The FPU-SLFR design and wave heading direction indicated in Figs. 6 and 7.

Analyzing motion response FPU using Ansys AQWA obtain the stress range each mooring lines. Stress range of each mooring lines obtained from the time domain analysis to the catenary mooring system based FPU motion responses in the heading direction $180^{\circ}$ so that resulting from the tensions due to each mooring lines affected when using SLFR and without using SLFR. Each mooring lines take the fatigue life process further between the stress range-failure and characteristics of the mooring line used against loading period head the DNV (Det Norske Veritas) and the API (American Petroleum Institute) criteria and then get the conclusion.

Table 4. FPU main dimension

\begin{tabular}{ll}
\hline \multicolumn{2}{l}{ Barge Hull Gas FPU } \\
\hline LOA & $160.5 \mathrm{~m}$ \\
$\mathrm{~B}$ & $50.0 \mathrm{~m}$ \\
$\mathrm{H}$ & $17.0 \mathrm{~m}$ \\
$\mathrm{~T}$ & $8.40 \mathrm{~m}$ \\
$\mathrm{Cb}$ & 0.98 \\
\hline
\end{tabular}

Table 5. FPU mooring data

\begin{tabular}{ll}
\hline Mooring Properties & \\
\hline Mass / Unit Length & $140 \mathrm{~kg} / \mathrm{m}$ \\
Outer Diameter & $0.115 \mathrm{~m}$ \\
Section Length & $1,200 \mathrm{~m}$ \\
Stiffness, EA & $1.0 \times 10^{9} \mathrm{~N}$ \\
Maximum Tension & $8.0 \times 10^{6} \mathrm{~N}$ \\
\hline
\end{tabular}

Table 6. Makassar strait wave scatter data

\begin{tabular}{llllllll}
\hline Hs/Tp & $2-3$ & $3-4$ & $4-5$ & $5-6$ & $6-7$ & $7-8$ & Total \\
\hline $0.00-0.25$ & 5.64 & 7.44 & 2.42 & 2.50 & 2.01 & 0.68 & 20.69 \\
$0.25-0.50$ & 4.77 & 13.42 & 7.19 & 6.06 & 5.77 & 1.36 & 38.57 \\
$0.50-0.75$ & 1.07 & 6.64 & 6.66 & 3.10 & 3.10 & 0.78 & 21.35 \\
$0.75-1.00$ & 0.27 & 2.93 & 3.32 & 2.45 & 1.48 & 0.29 & 10.74 \\
$1.00-1.25$ & 0.05 & 1.07 & 1.55 & 1.02 & 0.73 & 0.07 & 4.49 \\
$1.25-1.50$ & 0.00 & 0.19 & 1.04 & 0.68 & 0.53 & 0.02 & 2.46 \\
$1.50-1.75$ & 0.00 & 0.17 & 0.46 & 0.29 & 0.29 & 0.02 & 1.23 \\
$1.75-2.00$ & 0.00 & 0.00 & 0.17 & 0.19 & 0.07 & 0.00 & 0.43 \\
$2.00-2.25$ & 0.00 & 0.00 & 0.02 & 0.02 & 0.00 & 0.00 & 0.04 \\
Total & 11.80 & 31.86 & 22.83 & 16.31 & 13.98 & 3.22 & 100 \\
\hline
\end{tabular}

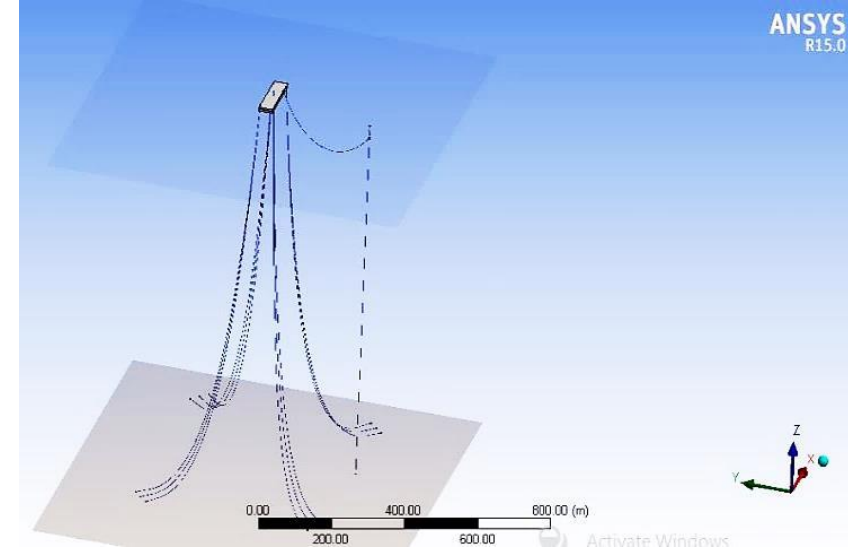

Figure 6. FPU and SLFR

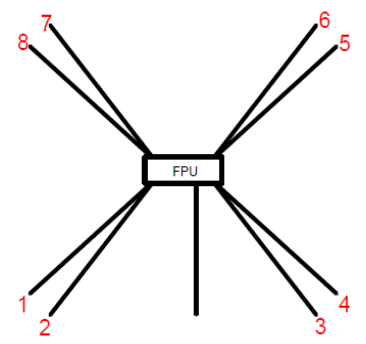

(a)

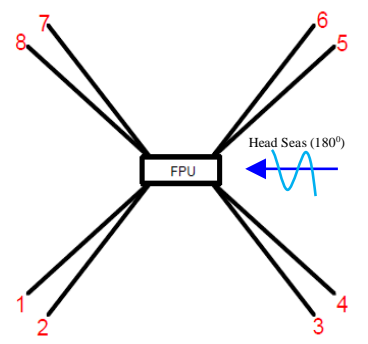

(b)
Figure 7. Mooring line numbering; (a) with SLFR and (b) without using SLFR

\section{Results and Discussions}

\subsection{Hydrostatic Analysis}

The hydrostatics FPU Gendalo-Gehem analysis results obtained from the hydrodynamic diffraction that considered the heave, roll and pitch motions. The hydrostatics generated from the FPU geometrical characteristics.

The FPU in Ansys Aqwa with and without using SLFR are very influential volumetric displacement, center of buoyancy position, distance COG to $\mathrm{COB}$ and metacentric height due to the the vertical motion modes (heave, roll and pitch motion). It has stiffness factor that may affect the damping factor becomes be smaller, so it will produce the highest characteristics result as shown in Table 7.

The FPU in horizontal motion mode (surge, sway, yaw motion) are also strongly important influential the stiffness of damping factor that do not rise up hydrostatic characteristics significantly.

\subsection{Response Amplitude Operator Analysis}

The results of RAO analysis with and without SLFR in head seas can be seen in Fig. 8. The response amplitude change over with and without SLFR condition. It proves that the mooring lines can reduce the FPU motion in harsh environment with $H_{s}=4.0$ meters and $T=7.7 \mathrm{sec}$. 
Table 7. Hydrostatic result using SLFR and without SLFR in Ansys AQWA

\begin{tabular}{|c|c|c|}
\hline Item & with SLFR & without SLFR \\
\hline \multicolumn{3}{|c|}{ Centre of Gravity Position } \\
\hline $\mathrm{X}:$ & $80.25 \mathrm{~m}$ & $80.25 \mathrm{~m}$ \\
\hline Y: & $25.00 \mathrm{~m}$ & $25.00 \mathrm{~m}$ \\
\hline $\mathrm{Z}:$ & $0.00 \mathrm{~m}$ & $0.00 \mathrm{~m}$ \\
\hline Heave(Z) & $80,665,544 \mathrm{~N} / \mathrm{m}$ & $80,666,000 \mathrm{~N} / \mathrm{m}$ \\
\hline $\operatorname{Roll}(\mathrm{RX})$ & $1.940 \mathrm{E}+08 \mathrm{~N} \cdot \mathrm{m} /{ }^{\circ}$ & $1.940 \mathrm{E}+08 \mathrm{~N} . \mathrm{m} /{ }^{\circ}$ \\
\hline $\operatorname{Pitch}(\mathrm{RY})$ & $2.923 \mathrm{E}+09 \mathrm{~N} \cdot \mathrm{m} /{ }^{\circ}$ & $2.923 \mathrm{E}+09 \mathrm{~N} \cdot \mathrm{m} /{ }^{\circ}$ \\
\hline \multicolumn{3}{|l|}{ Actual Volumetric } \\
\hline $\begin{array}{l}\text { Displacement } \\
\text { Equivalent Volumetric }\end{array}$ & $134,819.970 \mathrm{~m}^{3}$ & $134,819.91 \mathrm{~m}^{3}$ \\
\hline Displacement & $134,819.520 \mathrm{~m}^{3}$ & $134,819.52 \mathrm{~m}^{3}$ \\
\hline \multicolumn{3}{|c|}{ Centre of Buoyancy Position } \\
\hline $\mathrm{X}:$ & $80.25 \mathrm{~m}$ & $80.25 \mathrm{~m}$ \\
\hline $\mathrm{Y}:$ & $25.000002 \mathrm{~m}$ & $25.00 \mathrm{~m}$ \\
\hline $\mathrm{Z}:$ & $-4.1999927 \mathrm{~m}$ & $-4.2000031 \mathrm{~m}$ \\
\hline Cut Water Plane Area & $8,024.972 \mathrm{~m}^{2}$ & $8,025.018 \mathrm{~m}^{2}$ \\
\hline C.O.G. to C.O.B.(BG) & $4.1999927 \mathrm{~m}$ & $4.2000031 \mathrm{~m}$ \\
\hline \multicolumn{3}{|l|}{ Metacentric Heights } \\
\hline GMX: & $8.2007885 \mathrm{~m}$ & $8.2008057 \mathrm{~m}$ \\
\hline GMY: & $123.57906 \mathrm{~m}$ & $123.57912 \mathrm{~m}$ \\
\hline \multicolumn{3}{|l|}{ COB to Metacentre } \\
\hline BMX: & $12.400781 \mathrm{~m}$ & $12.400809 \mathrm{~m}$ \\
\hline BMY: & $127.77905 \mathrm{~m}$ & $127.77913 \mathrm{~m}$ \\
\hline \multicolumn{3}{|l|}{ Restoring Moments } \\
\hline MX: & $3,385,393 \mathrm{~N} \cdot \mathrm{m} /{ }^{\circ}$ & $3,385,399 \mathrm{~N} \cdot \mathrm{m} /{ }^{\circ}$ \\
\hline MY: & $51,015,060 \mathrm{~N} \cdot \mathrm{m} /{ }^{\circ}$ & $51,015,060$ N.m/ ${ }^{\circ}$ \\
\hline
\end{tabular}

When using SLFR, FPU motion characteristics do not exceed the maximum high waves well. It means that the RAO's amplitude responses are always smaller than the wave incident amplitude. In the surge, heave and pitch motions are shown in Figs. 8(a), 8(c) and 8(e). It shows that with and without using SLFR in head seas get the similar RAO. The maximum surge motion occurs when without using SLFR is $0.615 \mathrm{~m} / \mathrm{m}$ and the maximum heave motion occurs when using SLFR in $1.048 \mathrm{~m} / \mathrm{m}$. The maximum pitch motion occurs when without using SLFR is $2.225 \%$ m. In Fig. 8(d) shows that the maximum roll when using SLFR is $18.423 \times 10^{-6} \% / \mathrm{m}$. The response amplitude using SLFR are greater than without using SLFR too. It occurs while using SLFR is $0.207 \mathrm{rad} / \mathrm{sec}$ longer frequency duration than without using SLFR.

Meanwhile, sway, and yaw motion show that both are the different trend as shown in Figs. 8(b) and 8(f). The maximum sway motion when using SLFR is $9.354 \times 10^{-7} \mathrm{~m} / \mathrm{m}$ and the RAO significant difference occurs are from 0.1 to $0.657 \mathrm{rad} / \mathrm{sec}$. The maximum yaw motion occurs when using SLFR which is $12.671 \times 10^{-8} \% / \mathrm{m}$ and on the early frequency, $0.239 \mathrm{rad} / \mathrm{sec}$ occur the significant difference response because SLFR position is not centering of the mid ship so RAO when using SLFR duration occurs sooner. a

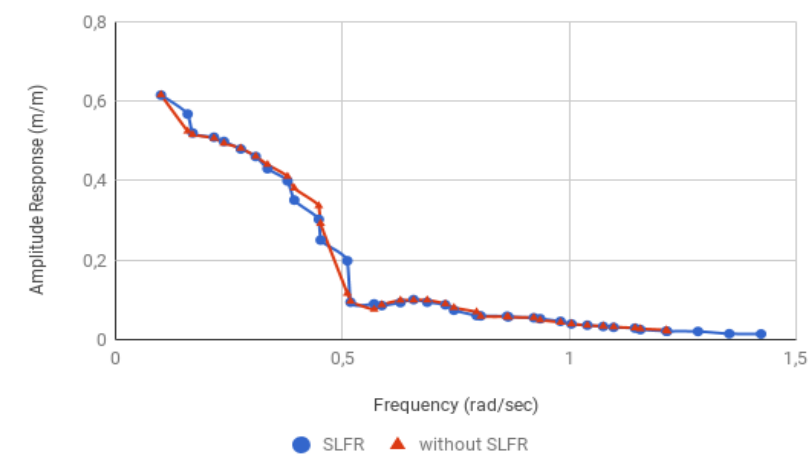

b

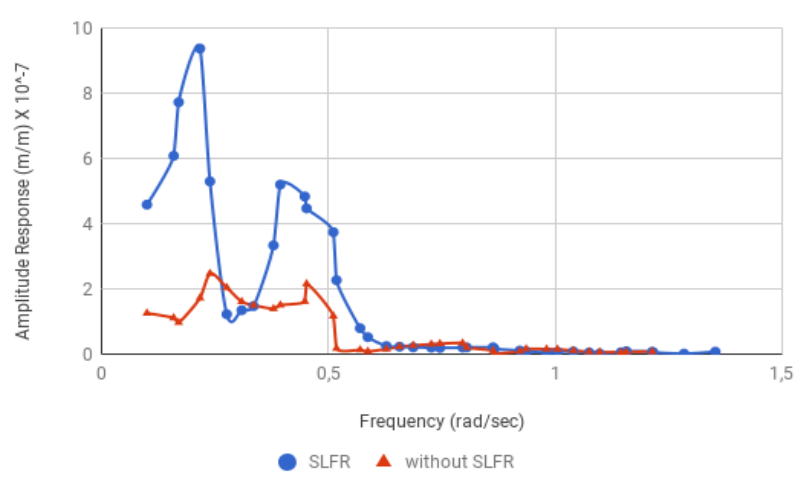

c RAO (Heave)

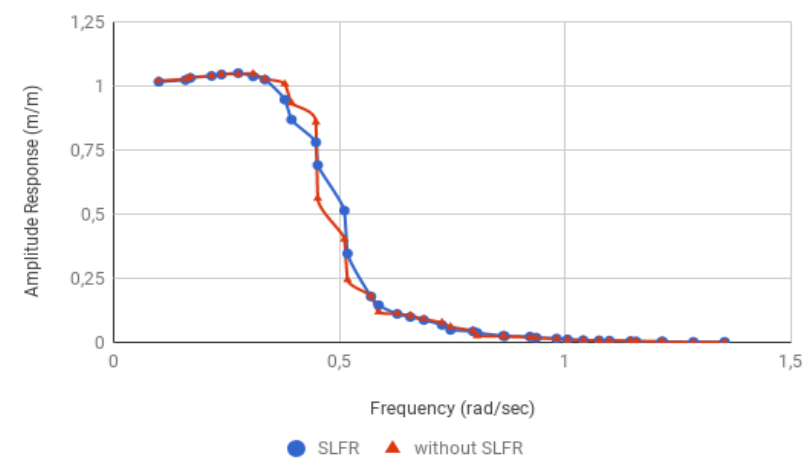

d

RAO (Roll)

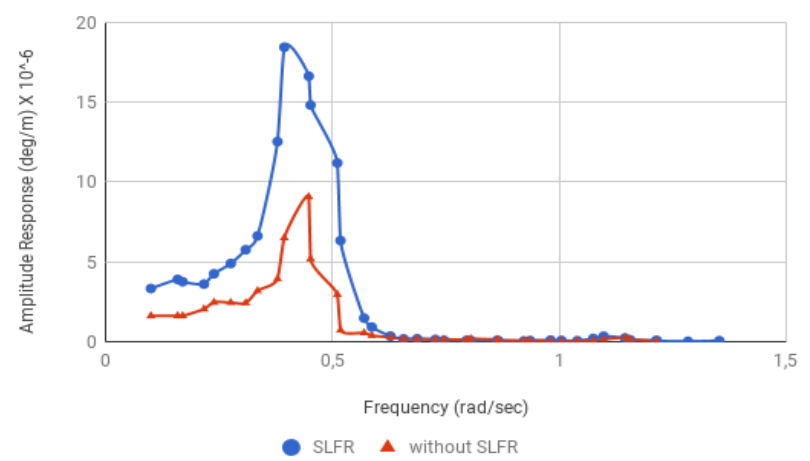


e

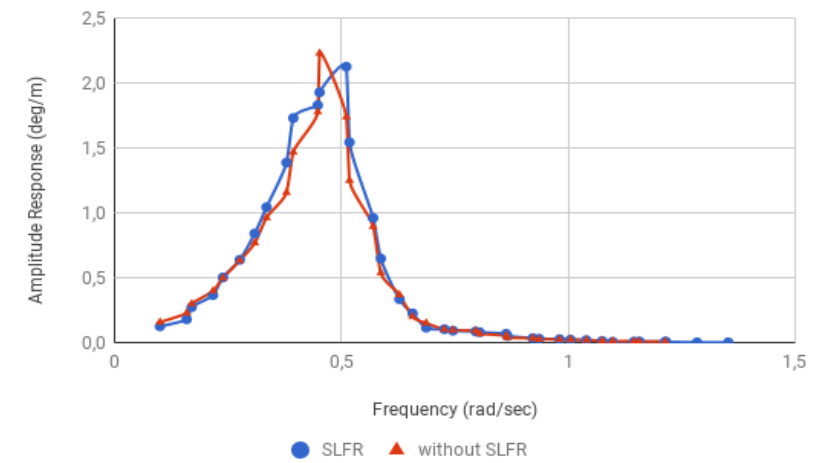

f

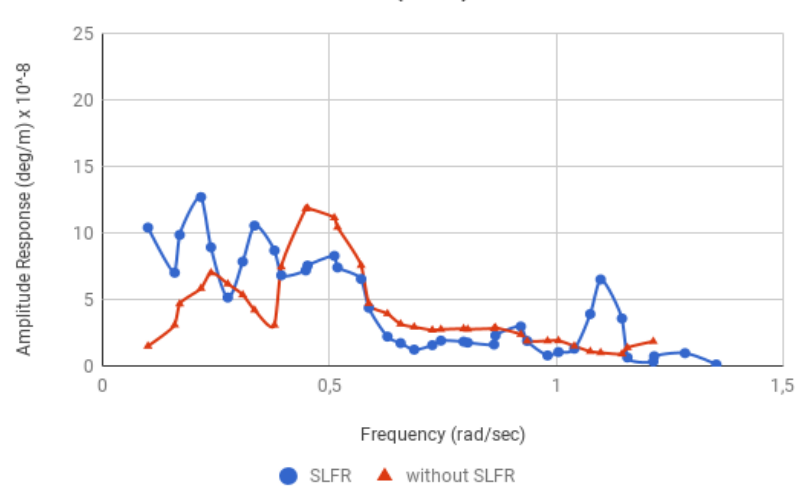

Figure 8. Comparison of RAO using SLFR and without SLFR; (a) surge motion; (b) sway motion; (c) heave motion; (d) roll motion; (e) pitch motion; and (f) yaw motion

\subsection{Stress Range Results}

After obtaining the RAO, then stress range can be determined by the maximum and minimum mooring lines tension within difference wave periods. In Fig. 9, the FPU mooring line tension occurs when using SLFR in head seas. From all mooring line tensions, tension trend generated is almost the same response. The maximum tension occurs in mooring line 4 worth $230,586.125 \mathrm{kN}$ in $9.22 \mathrm{sec}$, and the minimum tension occurs in mooring line 1 is $40,560.648 \mathrm{kN}$ in $11.12 \mathrm{sec}$ as shown in Table 8.

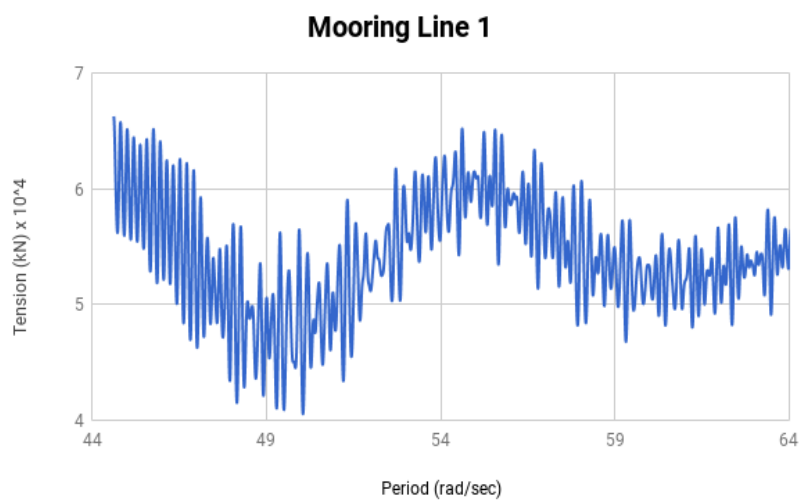

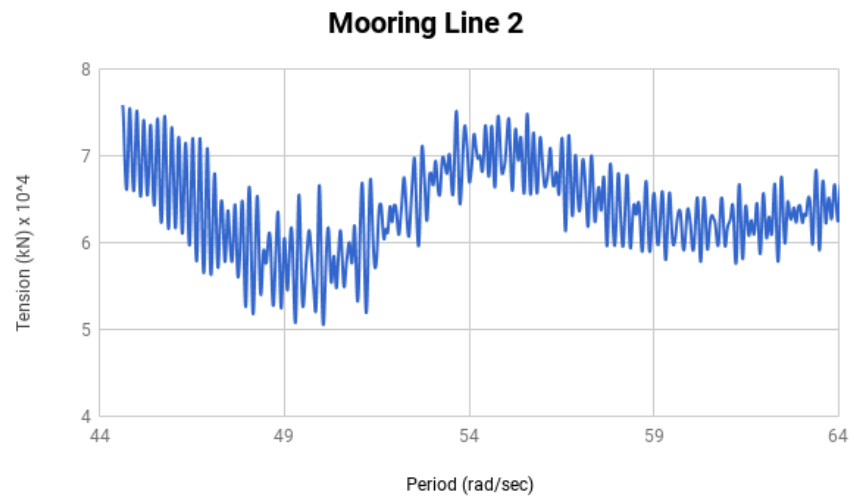
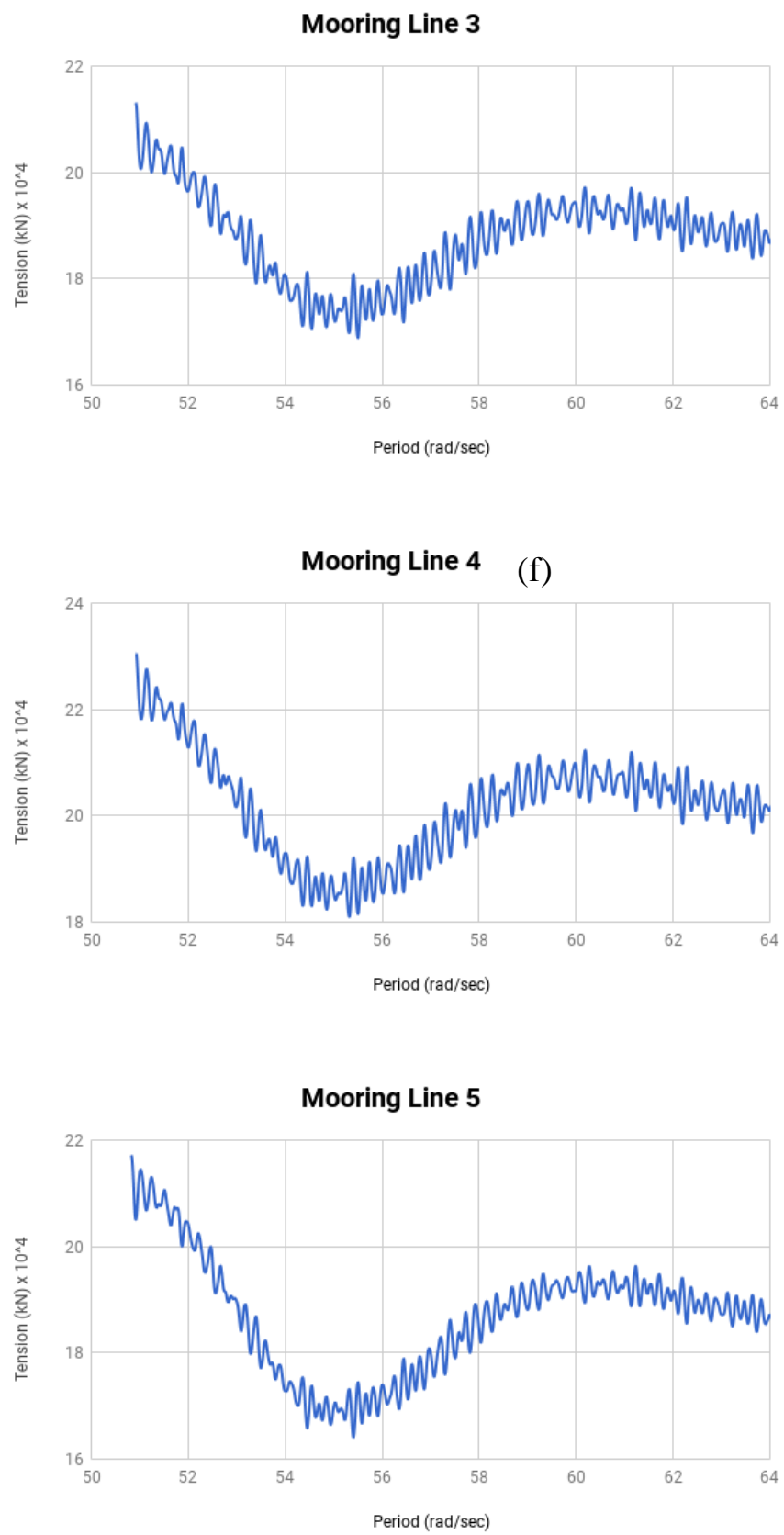

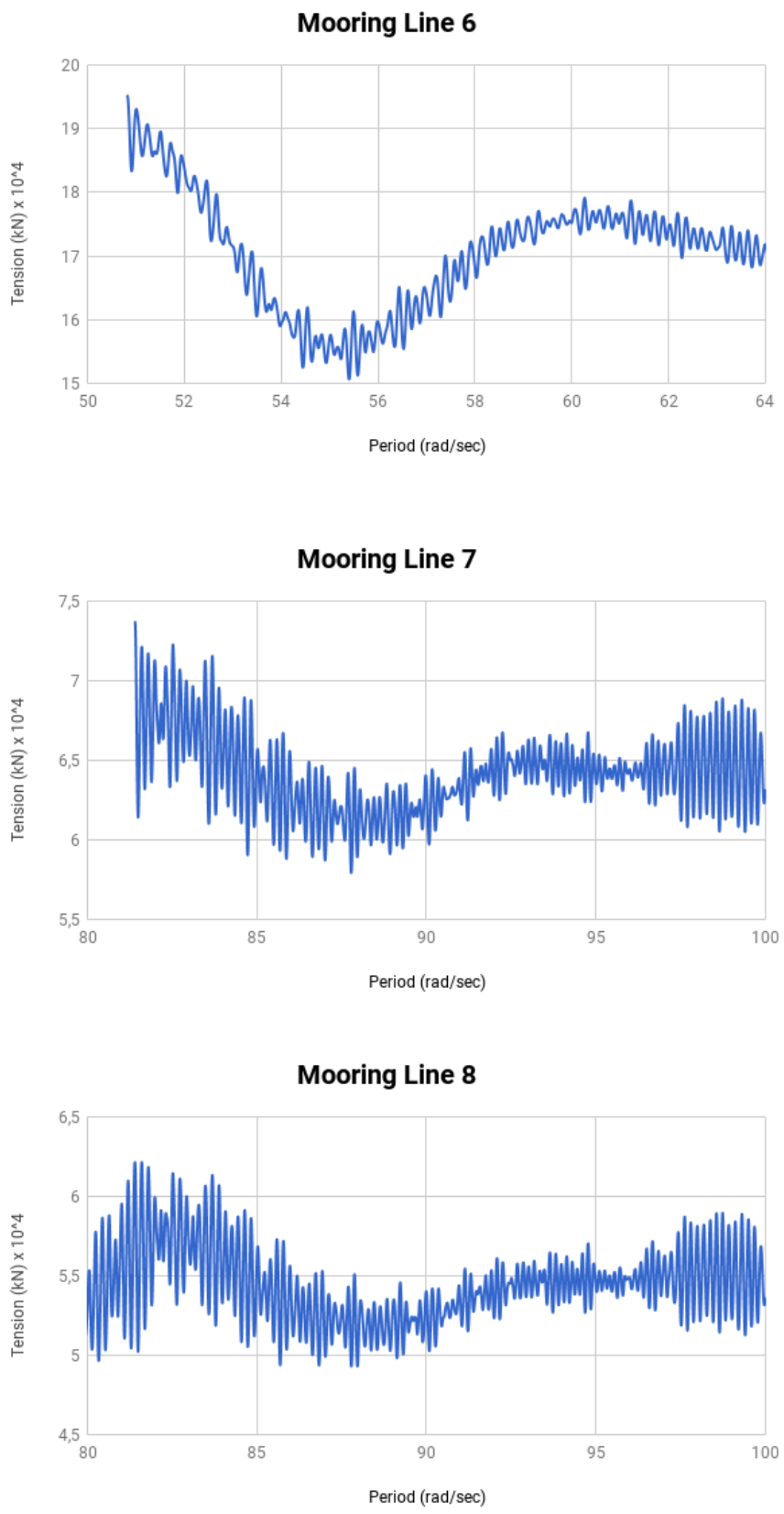

Figure 9. Tension of mooring line using SLFR

Table 8. Summary of mooring line tension using SLFR

\begin{tabular}{|c|c|c|c|c|}
\hline \multirow{2}{*}{$\begin{array}{l}\text { Mooring } \\
\text { Line }\end{array}$} & \multicolumn{3}{|c|}{ Tension $[\mathrm{kN}]$} & \multirow{2}{*}{$\begin{array}{l}\text { Period } \\
{[\mathrm{Sec}]}\end{array}$} \\
\hline & Maximum & Minimum & Range & \\
\hline 1 & $66,249.992$ & $40,560.648$ & $25,689.344$ & 11.12 \\
\hline 2 & $75,845.055$ & $50,511.129$ & $25,333.926$ & 10.46 \\
\hline 3 & $213,124.094$ & $168,838.700$ & $44,285.394$ & 9.72 \\
\hline 4 & $230,586.125$ & $182,490.890$ & $48,095.235$ & 9.22 \\
\hline 5 & $217,183.172$ & $167,975.230$ & $49,207.942$ & 9.32 \\
\hline 6 & $195,280.516$ & $150,674.780$ & $44,605.736$ & 9.53 \\
\hline 7 & $73,744.500$ & $57,945.961$ & $15,798.539$ & 12.42 \\
\hline 8 & $63,594.832$ & $45,602.555$ & $17,992.277$ & 10.40 \\
\hline
\end{tabular}

In Figure 10, the FPU mooring line tension occurs when without using SLFR in head seas. From all mooring line tensions, tension trend is very similar responses because no SLFR load affects. The maximum tension occurs in mooring line 5 is $236,337.797 \mathrm{kN}$ in $11.46 \mathrm{sec}$, and the minimum tension occurs in mooring line 8 is $49,361.270 \mathrm{kN}$ in 10.31 sec. Meanwhile, the maximum tension range in mooring line 5 is $57,418.188 \mathrm{kN}$ and the minimum tension range in mooring line 8 is $6,743.628 \mathrm{kN}$. For more information about summary mooring line tension when without using SLFR see Table 9.
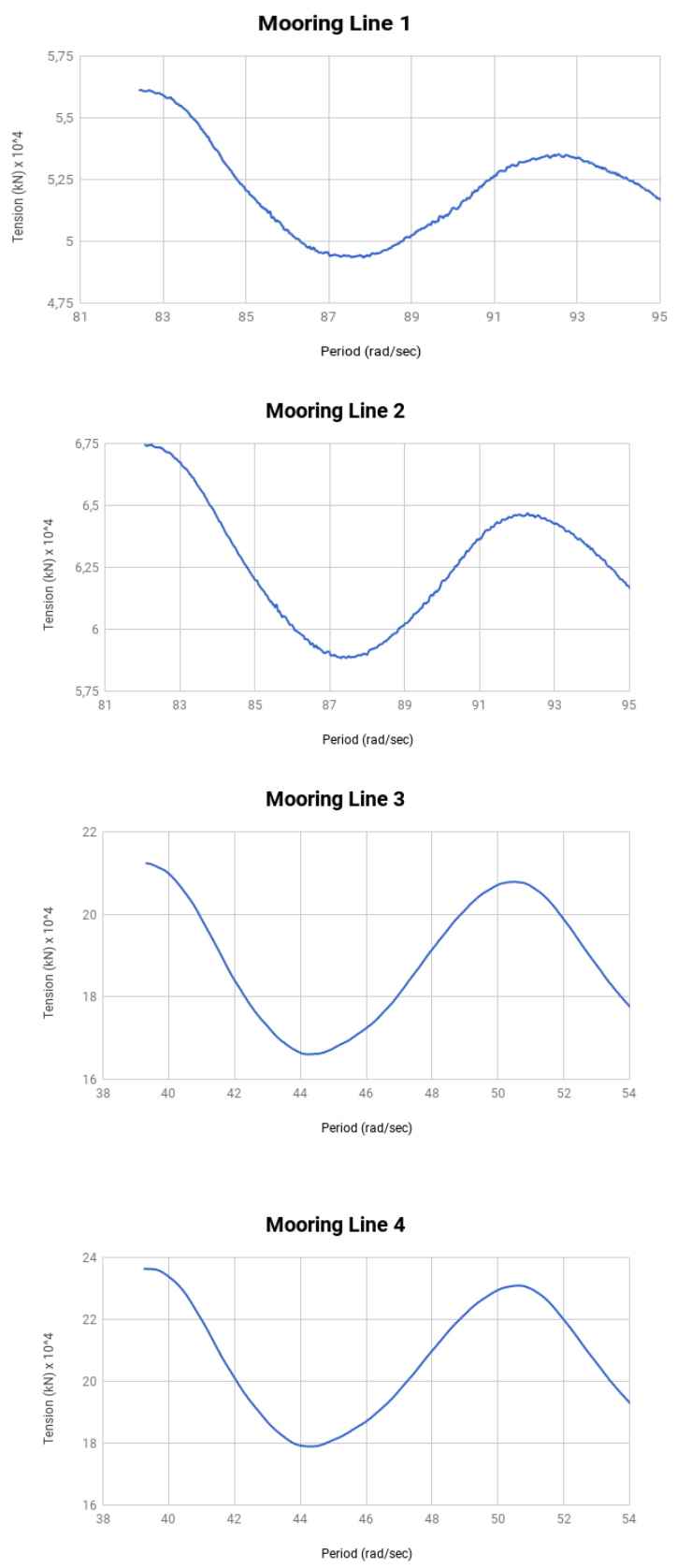

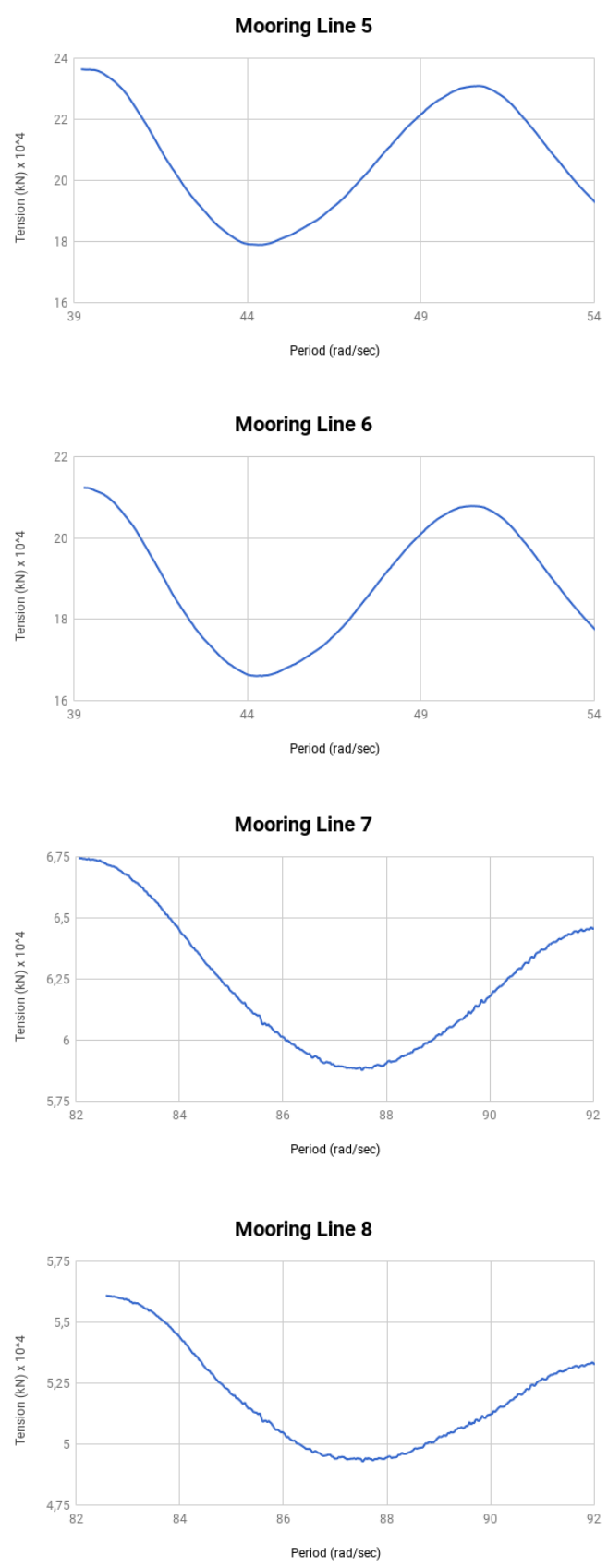

Figure 10. Tension of mooring line without using SLFR

Table 9. Summary of mooring line tension without using SLFR

\begin{tabular}{lllll}
\hline \multirow{2}{*}{$\begin{array}{l}\text { Mooring } \\
\text { Line }\end{array}$} & \multicolumn{3}{c}{ Tension $[\mathrm{kN}]$} & $\begin{array}{l}\text { Period } \\
{[\mathrm{Sec}]}\end{array}$ \\
\cline { 2 - 5 } & Maximum & Minimum & Range & 10.41 \\
\hline 1 & $56,131.527$ & $49,355.484$ & $6,776.043$ & 10.30 \\
2 & $67,466.961$ & $58,837.230$ & $8,629.731$ & 11.28 \\
3 & $212,374.688$ & $166,064.969$ & $46,309.719$ & 11.44 \\
4 & $236,306.781$ & $178,893.109$ & $57,413.672$ & 11.44 \\
5 & $236,337.797$ & $178,919.609$ & $57,418.188$ & 11.46 \\
6 & $212,346.016$ & $166,055.531$ & $46,290.485$ & 11.29 \\
7 & $67,454.625$ & $58,784.664$ & $8,669.961$ & 10.34 \\
8 & $56,104.898$ & $49,361.270$ & $6,743.628$ & 10.31 \\
\hline
\end{tabular}

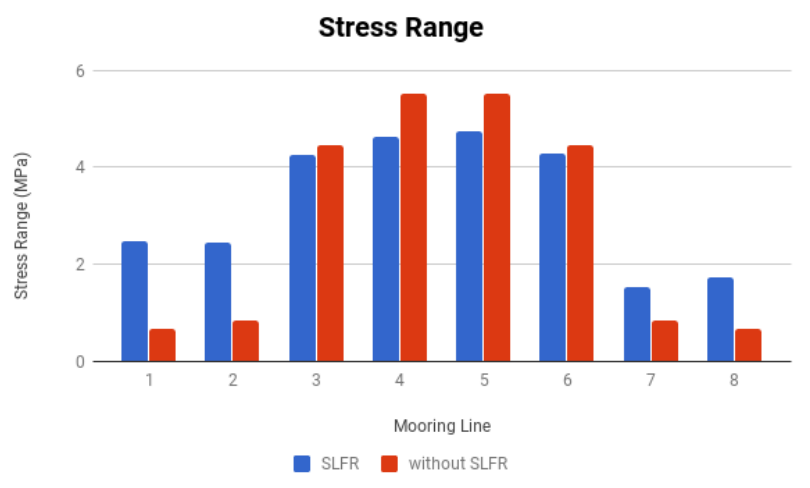

Figure 11. Comparison of stress range using SLFR and without SLFR

After obtaining the tension range in Table 9 and Table 10, the stress range of each mooring lines can be determined by calculating the six-strand wire rope of mooring line crosssectional area [15]. The cross-sectional area is $10.382 \times 10^{-6}$ $\mathrm{m}^{2}$.

The stress range of mooring lines using SLFR is differently received by each mooring lines as in Fig. 11. The maximum and minimum stress range of mooring line using SLFR are $4.740 \mathrm{MPa}$ with $9.32 \mathrm{sec}$ and $1.522 \mathrm{MPa}$ with $12.42 \mathrm{sec}$. While the stress range of mooring lines without using SLFR get the similar trend for each mooring lines. The maximum and minimum stress range is $5.531 \mathrm{MPa}$ in 11.46 sec and $0.650 \mathrm{MPa}$ in $10.31 \mathrm{sec}$.

\subsection{Fatigue Life Analysis Results}

From the stress range results, it is obtained the fatigue life of mooring lines. Then, it is determined by the number of cycles $(n)$, fatigue damage $(D)$ and fatigue life where the additional safety range about 0.67 [8].

Based on Fig. 12, the comparison of fatigue life of mooring lines with or without SLFR takes effect in the stress range and its period that get difference significantly in the mooring line 1 which is about $182.540 \times 10^{4}$ years because the SLFR located in midship area nearby the bow as in Fig. 7(a). When the wave incident in head seas happened, the mooring line 7 and 8 with SLFR get major structural responses as same as the mooring line 1 and 8 without SLFR. It is smaller tensions than other mooring lines. Consequently, the fatigue life using SLFR is smaller than without using SLFR.

At the same time, the fatigue life result using SLFR is 412 years on mooring line 4 and 5 . The fatigue life result without using SLFR is 6,636 years on mooring line 5. 


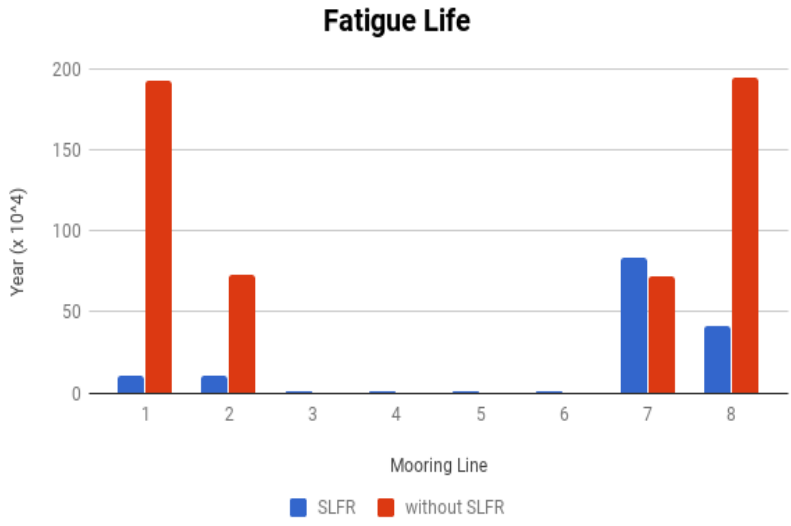

Figure 12. Comparison of fatigue life using SLFR and without SLFR

\section{Conclusion}

The fatigue analysis of catenary mooring system due to harsh environment in head seas have been performed using SLFR and without using SLFR. The general conditions can be drawn quite well because maximum RAO is less than the wave height. It means that the response amplitude always be smaller than wave incident amplitude, so that the maximum RAO due to the head seas in harsh environment with $H_{s}=$ 4.0 meters and $T=7.7 \mathrm{sec}$ in the highest surge motion without using SLFR is $0.615 \mathrm{~m} / \mathrm{m}$, the highest heave motion when using SLFR is $1.048 \mathrm{~m} / \mathrm{m}$ while the highest pitch motion without using SLFR is $2.23 \% \mathrm{~m}$. Another thing happened when using SLFR is about $0.207 \mathrm{rad} / \mathrm{sec}$ longer frequency than without using SLFR.

By catenary mooring system design accordingly and using SLFR calculated by head seas, the fatigue life result on catenary mooring systems in the harsh environment by using SLFR is 412 years on mooring line 4 and 5. Another the fatigue life result without using SLFR is 6,636 years on mooring line 5. The structure is still in safe condition because of the API design safety factor is about 300 years.

\section{Acknowledgements}

The authors would like to convey a great appreciation to PT. Chevron Indonesia Company, Balikpapan, East Kalimantan, Indonesia for supporting this research data.

\section{References}

[1] Faltinsen OM. Hydrodynamics of High-Speed Marine Vehicles. New York: Cambridge University Press; 2005. p. 421-426.

[2] Sun JW, Wang SQ. Study on Motion Performance of Deepwater Spar Platform under Different Mooring Methods. China: Period of Ocean University of China; 2010. p. 135-137.

[3] Chakrabarti SK. Hydrodynamic of Offshore Structures. USA Computational Mechanic Publication Southampton; 1987. p. 380-381.

[4] Saidee MH. Fatigue Analysis and Design of Mooring Systems: Assessment and Comparison of Different Methods. Master of Science Thesis. Norway: NTNU; 2015. p. 3-4.

[5] Vryh of Anchors BV. Anchor Manual: The Guide Anchoring. Netherlands: Capelle a/d Yssel; 2010. p. 7-8.

[6] Larsen K. Lecture Note: Mooring and Station Keeping of Floating Structures. Norway: NTNU; 2014. p. 10-13.

[7] Chrolenko MO. Dynamic Analysis and Design of Mooring Lines. Norway: NTNU; 2013. p. 3-4.

[8] API RP 2 SK. Recommended Practice for Design and Analysis of Station Keeping Systems for Floating Structures. USA: American Petroleum Institute; 2005. p. 30-31.

[9] Nugteren F. Flexible Riser Fatigue Analysis: Studying Conservatism in Flexible Riser Fatigue Analysis and Development of an Engineering Model to Study Influencing Parameters of Local Wire Stress. Master of Science Thesis. Netherlands: TU Delft; 2015. p. 10-12.

[10] Bannantine AJ, Comer JJ, Handrock LJ. Fundamental of Metal Fatigue Analysis. USA: Prentice Hall; 1990. p. 1-10.

[11] DNV OS E301. Position Mooring. Norway: Det Norske Veritas; 2004. p. 35-37.

[12] Nallayarasu. Offshore Structures Analysis and Design. India: Indian Institute of Technology; 2015. p. 99-100.

[13] API RP 2 RD. Design of Risers for Floating Production Systems (FPSs) and Tension-Leg Platforms (TLPs). USA: American Petroleum Institute; 1998. p. 55-56.

[14] Larsen CM, Svein S, Jacob Q. Handbook on Design and Operation of Flexible Pipes; B1 Design Analysis. Norway: MARINTEK - NTNU 4Subsea; 2014. p. 184-190.

[15] DNV OS E304. Offshore Mooring Steel Wire Ropes. Norway: Det Norske Veritas; 2015. p. 26-27. 